\title{
Cultivated Pastures Affect Nutrient Intake and Feeding Behavior of Sheep
}

\author{
J. V. Emerenciano Neto ${ }^{a, *}$, G. S. Difante ${ }^{\mathrm{b}}$, H. R. Medeiros ${ }^{\mathrm{c}}$, E. M. Aguiarc, L. S. Fernandes ${ }^{\mathrm{d}}$, T. F. M. \\ Trindade $^{c}$, M. G. Bezerra ${ }^{e}$, H. C. B. Oliveira ${ }^{c}$, \& R. C. P. Galvão ${ }^{c}$ \\ ${ }^{a}$ Federal University of Vale do São Francisco, Academic Collegiate of Animal Science, Petrolina, Brazil \\ ${ }^{b}$ Federal University of Mato Grosso do Sul, Faculty of Veterinary Medicine and Animal Sciences, \\ Campo Grande, Brazil \\ 'Federal University of Rio Grande do Norte, Specialized Academic Unit in Agrarian Sciences, Macaíba, Brazil \\ dFederal University of Paraíba, Center of Agrarian Sciences, Areia, Brazil \\ eFederal University of the Semi-Arid Region, Program in Soil and Water Management, Mossoró, Brazil \\ *Corresponding author: joao_neto@zootecnista.com.br \\ (Received 03-10-2019; Revised 11-12-2019; Accepted 21-01-2020)
}

\begin{abstract}
Cultivated pastures may increase the meat production of sheep, but it is necessary to understand the plant-animal relationships in a pastoral environment. This study aimed to assess the effect of forage cultivars on the intake and feeding behavior of sheep. Four treatments were evaluated, consisted of the cultivars Panicum maximum cvs. Aruana and Massai and Brachiaria brizantha cvs. Marandu and Piatã. Twenty-four sheep, male of the Santa Inês genotype, were used with six replications per treatment. Daily forage and nutrient intakes were evaluated in addition to time in grazing, rumination, and leisure activities. The animals in the pasture of Aruana grass demanded the most extended times of grazing and rumination $(p<0.05)$. The leisure time was higher $(p<0.05)$ in the animals kept in pastures of Piatã grass. The highest intakes of dry matter and crude protein in g/day $(p<0.05)$ were found in the animals kept in the pasture of Marandu grass, and a smaller intake was found in the animals kept in the pasture of Massai grass. Intake of leaf blades was higher $(p<0.05)$ in the animals kept in pastures of Massai and Marandu. The neutral detergent fiber intake did not differ among the cultivars. It is concluded that pasture structure and chemical composition of tropical forage cultivars influence the nutrient intake and feeding behavior of sheep. The low leaf blade offer of the pasture of the Aruana grass negatively affects the feeding behavior of the sheep, but the crude protein in forage of this cultivar favors the nutrient intake, feed conversion, and performance of sheep.
\end{abstract}

Keywords: Brachiaria brizantha; grazing; LIPE®; Panicum maximum; rumination

\section{INTRODUCTION}

In grazing livestock systems in tropical South American environments, the monoculture of perennial grasses of the genera Brachiaria and Panicum predominates with a forage production, concentrated in the rainy season (Sbrissia et al., 2017). The use of cultivated pastures is a valuable tool to increase the productivity of sheep but should be considered as a technology that requires knowledge of plant-animal interrelationships. The efficiency of the productive system of grazing animals is affected by changes in the feeding behavior under conditions that limit pasture intake due to the inability to maintain a high rate of dry matter intake (Galli et al., 1996). The understanding of feeding behavior of grazing animals makes it possible to define adequate pasture and animal management strategies and provides the ability to interfere positively with production results.

The composition of forage selected by grazing animals depends on several factors, including the composition of available forage species, the grazing season, the growth stage, the pasture structure, and the individual preferences of the animals. The grazing pattern of the animal determines the quality of the diet consumed, in which dry matter intake is essential for animal performance by determining the nutrient intake, considering as the main protein and the energy needed for the care of maintenance and production requirements (Fontenele et al., 2011).

The understanding of the relationship between plants and animals in grazing systems becomes indispensable for success in livestock, as there is a direct effect between feeding behavior, consumption, and animal performance. However, the measurement of herbage intake of grazing animals is difficult; there are no smooth and precise methodologies. Some research has used techniques to estimate herbage intake and nutritional parameters in grazing cattle such as external and internal markers (Azevedo et al. 2014), these types of sheep surveys are rare. Therefore, the objective of this study was to evaluate the effect of forage cultivars on forage and nutrient intake, as well as the feeding behavior of sheep in Brachiaria and Panicum pastures. 


\section{MATERIALS AND METHODS}

The experiment was conducted in an area of the Research Group in Forage (GEFOR), located at the Academic Unit Specialized in Agricultural Sciences - the Federal University of Rio Grande do Norte - UFRN, in Macaíba, Rio Grande do Norte, Brazil. The geographical coordinates of the experimental area are latitude $5^{\circ} 53^{\prime}$ $35.12^{\prime \prime}$ south and longitude $35^{\circ} 21^{\prime}$ 47.03" Westland 160 $\mathrm{m}$ of altitude.

\section{Animals, Experimental Design, and Diets}

The experimental area of 2.88 ha was split into two lots of 1.44 ha, with four modules of 0.36 ha for each cultivar, which were subdivided into six paddocks of equal area $(0.06 \mathrm{ha})$. The evaluation period was from April to September 2017, the rainy season in the region with an average monthly rainfall of $164 \mathrm{~mm}$.

The treatments consisted of 4 tropical kinds of grass, two cultivars of Panicum maximum: Aruana and Massai grasses; and two of Brachiaria brizantha: Marandu and Piatã grasses. Pastures were managed by intermittent stocking. The pasture rest periods were 52 days, the time necessary for the height of the canopy to reach $50 \mathrm{~cm}$. The occupation period of each paddock was 52 days, and the time was required so that approximately $50 \%$ of the available mass could be removed. To ensure the goals of height, we used the variable stocking rate according to the grass growth and the amount of available forage.

Samples were collected through manual grazing simulation during the evaluation periods of pasture availability. Morphological components (leaf blade and stem) were pre-dried at $55^{\circ} \mathrm{C}$, ground in a Wiley mill to $1 \mathrm{~mm}$, and subsequently analyzed (Table 1).

The chemical composition of samples were analyzed according to AOAC (2005): dry matter (DM) was determined by drying in an oven at $105^{\circ} \mathrm{C}$ for 16 hours (method 973.18); ashes by burning at $600^{\circ} \mathrm{C}$ for 4 hours (method 942.05); the crude protein (CP) was estimated indirectly from total nitrogen $(\mathrm{N})$ determined by Kjeldahl method (method 984.13), and acid detergent lignin (ADL) was determined with acid detergent fiber residue treated with $72 \%$ sulfuric acid (method 973.18). Neutral detergent fiber (NDF) and acid detergent fiber
(ADF) were determined according to Van Soest et al. (1991), using 16 microns polyester bags in Ankom 220 Fibre Analyzer (ANKOM Technology, Inc., NY, USA). We determined the in vitro dry matter digestibility (IVDMD) of the WCR varieties using the two-stage technique described by Tilley \& Terry (1963) for a period of $72 \mathrm{hr}$ using Ankom II Daisy Incubators (ANKOM Technologies, Inc.).

To evaluate the chemical composition of the forage (Table 1), samples were collected through manual grazing simulation during the evaluation periods of pasture availability. Twenty-four 90-day-old castrated male Santa Ines weaned lambs with average live weights of $23.8 \pm 1.6 \mathrm{~kg}$ were used for evaluation kept in the pasture during the day (from 7 a.m. to 4 p.m.) and housed in a shed with collective stalls during the night with access to water and mineral salt ad libitum. Gastrointestinal nematode infestation was monitored weekly by counting the number of eggs per gram of feces (EPG), where ever reached 500 eggs/g of feces was realized oral anthelmintic application.

\section{Sampling and Measurement}

The forage allowance (FA) was calculated by dividing forage mass (FM) available in pre-grazing by the occupation period (OP) with stocking rate (SR), expressed in $\mathrm{kg} \mathrm{DM} / 100 \mathrm{~kg}$ live weight on each day (FA= (FM/ OP)/SR), according to Sollenberger et al. (2005). The animals were weighed weekly, and the average daily gain (ADG, g/day) was calculated by the difference between the weight of the animals at the beginning and the end of the experiment divided by the experiment days.

During the experiment, four periods (every two months) of marker delivery and feces collection were performed during two occupation stages. Those were the first and last days of the paddock occupation, to estimate the fecal output of DM (FO; g/animal/day) using LIPE ${ }^{\circledR}$ as an external marker (Saliba et al., 2015). Capsules containing $250 \mathrm{mg}$ of LIPE® were orally introduced for seven days (one capsule per animal per day) at 8 a.m. Feces were collected directly from the rectal bulb during the 5-day collection period, once a day. Feces started to be collected two days after the start of marker administration so that homogenization could occur throughout the entire digestive tract. Afterward, the

Table 1. Chemical composition of the morphological components in tropical pastures

\begin{tabular}{lccccccc}
\hline \multirow{2}{*}{ Component of tropical pastures } & \multicolumn{9}{c}{ Chemical composition (g/kg DM) } \\
\cline { 2 - 7 } & DM & CP & MM & NDF & ADF & ADL & IVDMD \\
\hline Marandu grass (leaf blade) & 245 & 150 & 77 & 618 & 319 & 41 & 684 \\
Marandu grass (stem) & 212 & 84 & 78 & 726 & 444 & 61 & 603 \\
Piatã grass (leaf blade) & 273 & 120 & 71 & 656 & 331 & 38 & 668 \\
Piatã grass (stem) & 241 & 67 & 68 & 746 & 445 & 58 & 580 \\
Massai grass (leaf blade) & 307 & 97 & 78 & 744 & 416 & 52 & 602 \\
Massai grass (stem) & 288 & 45 & 67 & 810 & 498 & 72 & 549 \\
Aruana grass (leaf blade) & 236 & 162 & 86 & 707 & 369 & 60 & 650 \\
Aruana grass (stem) & 238 & 85 & 73 & 767 & 474 & 73 & 557 \\
\hline
\end{tabular}

Note: $\mathrm{DM}=$ dry matter, $\mathrm{MM}=$ mineral matter, $\mathrm{CP}=$ crude protein, $\mathrm{NDF}=$ Neutral detergent fiber, $\mathrm{ADF}=$ acid detergent fiber, $\mathrm{ADL}=$ acid detergent lignin, IVDMD $=$ in vitro dry matter digestibility. 
fecal samples were homogenized, dried $\left(55^{\circ} \mathrm{C}\right.$ for $\left.72 \mathrm{~h}\right)$, and ground $(1 \mathrm{~mm})$ for further analysis.

LIPE® concentration in feces was determined using infrared spectroscopy in the Simoes and Saliba laboratory. The fecal output was estimated based on the ration of the amount of marker administrated to marker concentration in feces:

$$
\mathrm{FO}_{(\mathrm{g} / \text { animal/day })}=(\mathrm{MAO} / \mathrm{MCF}) \times 100
$$

where $F O$ is the fecal output, $M A O$ is the marker amount offered (LIPE囚), and MCF is the marker concentration in feces $(\mathrm{g} / \mathrm{kg} \mathrm{DM})$. The DMI estimate was obtained using the following equation:

$$
\mathrm{DMI}_{(\mathrm{g} / \mathrm{day} \mathrm{DM})}=\mathrm{FO} \times \mathrm{MCF} / \mathrm{MCFO}
$$

where $F O$ is the fecal output (g/day DM), MCF is the marker concentration in feces $(\mathrm{g} / \mathrm{kg} \mathrm{DM})$, and MCFo is the marker concentration in forage $(\mathrm{g} /$ day $\mathrm{DM})$. Intake of the leaf blade and stem (g/day) was estimated by the proportion of the mass of each morphological component disappeared from the picket during grazing, and this proportion was applied in the dry matter consumption, once the base diet was pasture only. The nutrient intake was estimated by the sum of the ingested amount in each morphological component.

Evaluations of the intake pattern were conducted by observations, which were made in 24 -hour shifts, and the animals' activities were recorded every 5 minutes. The animals were evaluated visually for feeding behavior, with three test animals for each observer. The biting rate was calculated from the time required for animals to perform 20 bites, then transformed into bites per minute (Hodgson, 1985). The observed activities were grazing, rumination, and idle times. All observations for the day were added up for each variable and expressed in h/day. Feeding and rumination efficiency $\left(\mathrm{g}^{\mathrm{DM}} / \mathrm{h}\right.$ and $\mathrm{g}^{\mathrm{NDF}} / \mathrm{h}$ ) were obtained by dividing the mean daily DM and NDF intake by the total time spent in grazing and rumination in 24 hours, respectively (Burger et al., 2000).

\section{Statistical Analysis}

The experimental design was a randomized block design (possible effect of the area), the data were analyzed for variance and the averages compared by the Tukey test at 5\% significance, using the statistical program SISVAR 5.6 (Ferreira, 2011). The model for data analysis was as follows:

$$
Y_{i j}=\mu+F_{i}+C_{j}+e_{i j k}
$$

where $Y_{i j k} 1$ is the dependent variable, $\mu$ is the overall mean, $F_{i}$ is the effect of the cultivar (Marandu grass, Massai grass, Aruana grass. and Piatã grass), $C_{j}$ is the effect of the block, and $e_{i j k}$ is the error term.

Correlations were obtained by Pearson's correlation analysis and the t-test, considering significance at $p<0.05$. The criterion for the classification of the correlation coefficient was $r \geq 80 \%$ meaning a strong association and $50 \%<r \leq 70 \%$ indicating a moderate correlation.

\section{RESULTS}

The lowest forage and leaf blade allowance were observed in the Aruana grass pastures (Table 2), while Massai pastures displayed the lowest stem allowance $(p<0.05)$. The highest dry matter intake (DMI) as $g /$ day was observed in the animals kept in Marandu grass pastures and the lowest in those kept in Massai grass pastures $(\mathrm{p}<0.05)$. The dry matter intake in \%LW did not differ according to the cultivars $(p>0.05)$; the average intake was $2.43 \%$ of their live weights in dry forage.

The highest intake of leaf blades was observed in the animals kept in pastures of Massai and Marandu grass $(p<0.05)$ and the highest intake of the stem in the animals kept in Aruana grass pasture. The highest crude protein intake $(\mathrm{CPI})$ as g/day and \% LW $(\mathrm{p}<0.05)$ were obtained by the animals kept in Marandu grass pastures and the lowest in Massai grass pastures (Table 3). Intake of mineral matter (MMI), neutral detergent fiber (NDFI), and acid detergent fiber (ADFI) in \% LW did not differ according to cultivars ( $>0.05)$, followed the same behavior of DMI in \% LW. The highest ADFI in $\mathrm{g} /$ day and acid detergent lignin (ADLI) as g/day and \% LW were observed in the animals in Aruana grass. The MMI in g/ day was higher in the animals kept in Marandu grass pastures. NDFI did not differ according to the cultivars ( $p>0.05$ ), with an average intake of $474.23 \mathrm{~g} /$ day of NDF.

The animals kept in Aruana grass pastures demanded the most extended $(p<0.05)$ grazing time (Table $4)$. The highest bit rates $(p<0.05)$ were observed in the animals kept on Marandu and Aruana grasses pastures and the lowest in Massai and Piatã pastures (Table 4). The highest time spent on rumination, and the shortest leisure time was observed in the sheep kept in the Aruana grass pastures $(p<0.05)$. The animals kept in

\begin{tabular}{|c|c|c|c|c|c|}
\hline \multirow{2}{*}{ Variables } & \multicolumn{4}{|c|}{ Forages } & \multirow{2}{*}{$\mathrm{CV}(\%)$} \\
\hline & Marandu & Piatã & Massai & Aruana & \\
\hline Forage allowance (kg DM/ 100 kg LW) & $47.51^{\mathrm{a}}$ & $47.80^{\mathrm{a}}$ & $46.79^{a}$ & $38.33^{\mathrm{b}}$ & 14.03 \\
\hline Leaf blade allowance (kg DM/ 100 kg LW) & $26.35^{\mathrm{b}}$ & $27.98^{\mathrm{b}}$ & $34.01^{\mathrm{a}}$ & $18.14^{c}$ & 17.57 \\
\hline Stem allowance (kg DM/ 100 kg LW) & $21.16^{\mathrm{a}}$ & $19.82^{\mathrm{a}}$ & $12.78^{\mathrm{b}}$ & $20.20^{\mathrm{a}}$ & 14.89 \\
\hline Dry matter intake (g/day) & $730.92^{a}$ & $698.90^{b}$ & $623.65^{\mathrm{d}}$ & $655.23^{c}$ & 2.17 \\
\hline Dry matter intake (\%LW) & 2.66 & 2.59 & 2.29 & 2.21 & 12.03 \\
\hline Leaf blade intake (g/day) & $543.76^{\mathrm{a}}$ & $514.81^{b}$ & $546.16^{a}$ & $360.33^{c}$ & 2.26 \\
\hline Stem intake (g/day) & $187.15^{\mathrm{b}}$ & $184.09^{b}$ & $77.48^{\mathrm{c}}$ & $294.90^{\mathrm{a}}$ & 2.20 \\
\hline
\end{tabular}
Aruana grass pastured continuously as long as they

Table 2. Forage supply and dry matter intake by sheep in pastures of tropical pastures

Note: $\mathrm{DM}=$ dry mater, $\mathrm{LW}=$ live weight, Means in the same row with different superscripts differ significantly ( $\mathrm{p}<0.05$ ). 
Table 3. Intake of nutritional components by sheep in pastures of tropical pastures

\begin{tabular}{|c|c|c|c|c|c|}
\hline \multirow{2}{*}{ Variables } & \multicolumn{4}{|c|}{ Forages } & \multirow{2}{*}{$\mathrm{CV}(\%)$} \\
\hline & Marandu & Piatã & Massai & Aruana & \\
\hline Crude protein intake (g/day) & $97.29^{a}$ & $74.11^{c}$ & $56.46^{\mathrm{d}}$ & $83.44^{\mathrm{b}}$ & 2.12 \\
\hline$(\% \mathrm{LW})$ & $0.35^{\mathrm{a}}$ & $0.27^{b}$ & $0.21^{\mathrm{c}}$ & $0.28^{\mathrm{b}}$ & 11.44 \\
\hline Mineral matter intake (g/day) & $56.47^{a}$ & $49.07^{c}$ & $47.79 c$ & $52.52^{b}$ & 2.14 \\
\hline$(\% \mathrm{LW})$ & 0.21 & 0.18 & 0.18 & 0.18 & 11.49 \\
\hline Neutral detergent fiber intake (g/day) & 471.92 & 475.05 & 469.11 & 480.94 & 2.18 \\
\hline (\%LW) & 1.72 & 1.76 & 1.72 & 1.63 & 11.75 \\
\hline Acid detergent fiber intake (g/day) & $256.56^{\mathrm{bc}}$ & $252.32^{\mathrm{c}}$ & $265.79^{b}$ & $272.74^{\mathrm{a}}$ & 2.16 \\
\hline$(\% \mathrm{LW})$ & 0.94 & 0.94 & 0.98 & 0.92 & 11.73 \\
\hline Acid detergent lignin intake (g/day) & $33.71^{b}$ & $30.24^{c}$ & $33.98^{b}$ & $43.15^{\mathrm{a}}$ & 2.10 \\
\hline$(\% \mathrm{LW})$ & $0.12^{\mathrm{b}}$ & $0.11^{\mathrm{b}}$ & $0.13^{\mathrm{b}}$ & $0.15^{\mathrm{a}}$ & 11.36 \\
\hline
\end{tabular}

Note: $\mathrm{LW}=$ live weight, means in the same row with different superscripts differ significantly $(\mathrm{p}<0.05)$.

Table 4. Time of grazing, rumination, and leisure of sheep kept on grasses of tropical grasses

\begin{tabular}{|c|c|c|c|c|c|}
\hline \multirow{2}{*}{ Variables } & \multicolumn{4}{|c|}{ Forages } & \multirow{2}{*}{$\mathrm{CV}(\%)$} \\
\hline & Maradu & Piatã & Massai & Aruana & \\
\hline Grazing time (h/day) & $8.26^{\mathrm{b}}$ & $7.38^{c}$ & $8.10^{\mathrm{b}}$ & $9.00^{\mathrm{a}}$ & 3.84 \\
\hline Biting rate (bit/min) & $47.17^{a}$ & $36.24^{b}$ & $35.57^{b}$ & $44.10^{\mathrm{a}}$ & 21.77 \\
\hline Rumination time (h/day) & $7.13^{\mathrm{b}}$ & $7.10^{\mathrm{b}}$ & $7.81^{\mathrm{b}}$ & $8.81^{\mathrm{a}}$ & 7.89 \\
\hline Leisure time (h/day) & $8.41^{\mathrm{ab}}$ & $9.26^{\mathrm{a}}$ & $8.03^{\mathrm{b}}$ & $6.22^{\mathrm{c}}$ & 9.62 \\
\hline
\end{tabular}

Note: $\mathrm{LW}=$ live weight, means in the same row with different superscripts differ significantly $(\mathrm{p}<0.05)$.
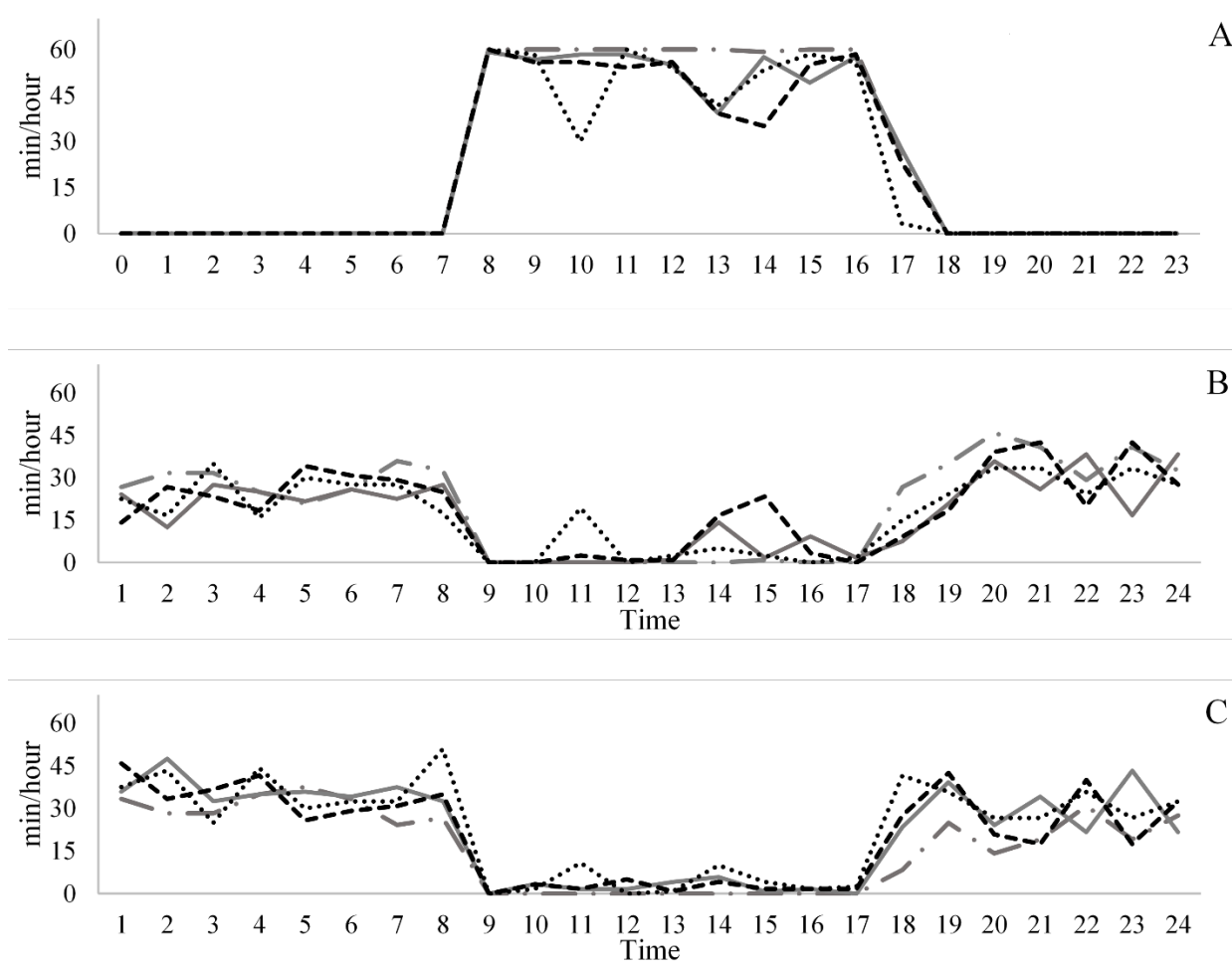

Figure 1. Grazing (A), rumination (B) and leisure/idle (C) activities of sheep on pastures of tropical grasses according to the time. Aruana $(-\cdots)$, Marandu ( - ), Massai (----•), Piatã $(\cdots . . . . . . .$.$) .$

remained in the pasture (7 a.m. to 4 p.m.), the animals kept in the other cultivars reduced the time of grazing in the period between 1 p.m. and 3 p.m. (Figure 1A). After the grazing period, these animals divided their time into rumination and leisure activities, with predominance for rumination in the period between 5 p.m. and 11 p.m. (Figure 1B) and for leisure between 11 p.m. and 07 a.m. of the following day (Figure 1C).

The highest feed efficiency $\left(\mathrm{g}^{\mathrm{DM}} / \mathrm{h}\right.$ and $\left.\mathrm{g}^{\mathrm{NDF}} / \mathrm{h}\right)$ was observed in the animals kept in Piatã pastures $(p<0.05)$ 
Table 5. Efficiency of feed and rumination, average daily gain, feed conversion of sheep on pastures of tropical grasses

\begin{tabular}{|c|c|c|c|c|c|}
\hline \multirow{2}{*}{ Variables } & \multicolumn{4}{|c|}{ Forages } & \multirow{2}{*}{$\mathrm{CV}(\%)$} \\
\hline & Marandu & Piatã & Massai & Aruana & \\
\hline Efficiency of feed (gDM/ h) & $88.50^{\mathrm{b}}$ & $94.89^{a}$ & $77.06^{c}$ & $72.80^{c}$ & 4.24 \\
\hline Efficiency of feed (gNDF/ h) & $57.15^{\mathrm{bc}}$ & $64.50^{a}$ & $57.96^{\mathrm{b}}$ & $53.44^{c}$ & 8.94 \\
\hline Efficiency of rumination $(\mathrm{gDM} / \mathrm{h})$ & $103.16^{\mathrm{a}}$ & $99.25^{a}$ & $80.31^{\mathrm{b}}$ & $74.57^{\mathrm{b}}$ & 9.12 \\
\hline Efficiency of rumination (gNDF/ h) & $66.60^{\mathrm{a}}$ & $67.46^{\mathrm{a}}$ & $60.40^{\mathrm{ab}}$ & $54.73^{\mathrm{b}}$ & 8.94 \\
\hline Average daily gain (g/day) & $46.97^{\mathrm{ab}}$ & $41.36^{\mathrm{b}}$ & $42.63^{b}$ & $65.15^{a}$ & 35.75 \\
\hline Feed conversion & $15.70^{\mathrm{a}}$ & $16.89^{a}$ & $14.63^{\mathrm{a}}$ & $10.06^{\mathrm{b}}$ & 14.61 \\
\hline
\end{tabular}

Note: $\mathrm{DM}=$ dry matter, NDF= neutral detergent fiber, means in the same row with different superscripts differ significantly $(\mathrm{p}<0.05)$.

Table 6. Correlation coefficients between variables of feeding behavior, intake and feed conversion of sheep on pastures of tropical grasses

\begin{tabular}{cccccccccc}
\hline & GT & RT & LT & LBI & SI & ADLI & FE & RE & FC \\
\hline GT & - & $0.66^{*}$ & $-0.87^{*}$ & $0.70^{*}$ & $0.53^{*}$ & $0.87^{*}$ & $-0.82^{*}$ & $0.84^{*}$ & $-0.51^{*}$ \\
RT & - & - & $-0.94^{*}$ & $0.58^{*}$ & $0.40^{\mathrm{NS}}$ & $0.71^{*}$ & $-0.75^{*}$ & $0.81^{*}$ & $-0.31^{\mathrm{NS}}$ \\
LT & - & - & - & $-0.67^{*}$ & $-0.50^{*}$ & $-0.83^{*}$ & $0.82^{*}$ & $-0.92^{*}$ & $0.40^{\mathrm{NS}}$ \\
LBI & - & - & - & - & $-0.85^{*}$ & $-0.87^{*}$ & $-0.71^{*}$ & $0.57^{*}$ & $0.39^{\mathrm{NS}}$ \\
SI & - & - & - & - & - & $0.70^{*}$ & $-0.17^{\mathrm{NS}}$ & $0.73^{*}$ & $-0.22^{\mathrm{NS}}$ \\
ADLI & - & - & - & - & - & - & $-0.75^{*}$ & $0.82^{*}$ & $-0.56^{*}$ \\
FE & - & - & - & - & - & - & - & $-0.58^{*}$ & $0.55^{*}$ \\
RE & - & - & - & - & - & - & - & - & $0.55^{*}$ \\
FC & - & - & - & - & - & - & - & - & - \\
\hline
\end{tabular}

Note: $\mathrm{GT}=$ grazing time, $\mathrm{RT}=$ rumination time, $\mathrm{LT}=$ leisure time, $\mathrm{LBI}=$ leaf blade intake, $\mathrm{SI}=$ stem intake, $\mathrm{ADLI}=\mathrm{Acid}$ detergent lignin intake, $\mathrm{FE}=$ feed efficiency, $\mathrm{RE}=$ rumination efficiency, $\mathrm{FC}=$ feed conversion, $\mathrm{NS}=($ Not significant $),{ }^{*}=(\mathrm{p}<0.05)$.

(Table 5). The pastures of Marandu and Piatã grasses provided the greater $(\mathrm{p}<0.05)$ rumination efficiency ( $\mathrm{g}^{\mathrm{DM}} / \mathrm{h}$ and $\mathrm{g}^{\mathrm{NDF}} / \mathrm{h}$ ) than the Aruana grass. The highest average daily gain (ADG) and the lowest feed conversion (FC) were observed in the Aruana grass pasture animals when compared to those maintained on pastures of Massai and Piatã grasses (Table 5). The main variables that showed significant correlations $(\mathrm{p}<0.05)$, and moderate to high magnitude are presented in Table 6.

\section{DISCUSSION}

Forage and morphological components allowance were the result of the volumetric density of these components in the pasture structure, since all the pastures were $50 \mathrm{~cm}$ high in the pre-grazing. The highest leaf blade and lowest stem supply observed in Massai pastures can be a result of the high density of tillers of this cultivar (Luna et al., 2014). The highest supply of stem in the other cultivars can be explained by the forage supply above $20 \mathrm{~kg} \mathrm{DM} / 100 \mathrm{~kg} \mathrm{LW}$. According to Gómez et al. (2010), in intermittent stocking, from this value occurs excessive accumulation of stems and dead material, which also causes a decrease in the quality of the forage offered.

The DMI (g/day) was directly related to the neutral detergent fiber content of the cultivars (Table 1), the animals that grazed forage with lower NDF obtained higher intake of dry matter. According to Bosa et al. (2012), the concentration of NDF in fodder is inversely related to dry matter intake by the animal. That is, the higher the NDF content, the lower the total intake. The DMI was lower than the $3.62 \%$ of LW observed by Pereira et al. (2018), for sheep in feedlot fed hay of Massai grass. The highest intake obtained by the authors was a result of the use of a protein concentrate, which allows an additive effect on total intake (Mabrouk et al., 2008). This effect was also observed by Jochims et al. (2010), who observed a lower intake of total DM in animals kept exclusively in millet pasture, and this was only $67 \%$ of the total intake of the animals that received supplements.

The animals kept in Massai and Marandu pastures displayed the highest intake of leaf blades $(\mathrm{p}<0.05)$. Although the highest intake of total forage (g/day) was observed in the animals that consumed Marandu grass, the greater supply of leaf blades observed in the Massai grass (Table 2) enabled a greater selection of this component by the animals. The lower ingestion of stem by the animals kept in the Massai grass supports this observation. The same reasoning explains the higher intake of stem by the animals kept in grasses of Aruana grass confirmed by the high and negative correlation (Table 6) between leaf blade and stem consumption. Usually, the animals prefer the leaves instead of the stems, because they are more digestible and nutritious; mature plants are also rejected. However, in pastures with less forage supply, the animals also consume the other parts of the plants (Tarazona et al. 2012).

The CPI was directly related to the $\mathrm{CP}$ concentration observed in the morphological components of the cultivars (Table 1). Although the highest CP concentration in the leaf was observed in the Aruana grass cultivar, the lower intake of this component by the animals in this cultivar made the CPI intermediate between 
Marandu and Massai grasses. Pereira et al. (2018) observed CPI of $0.48 \%$ LW in sheep fed with Massai hay and concentrated in the ratio $(2: 1)$. The difference in intake between the studies can be attributed to the use of concentrated supplements. The intake of this nutrient is the variable that most affects animal performance (Goes et al., 2018). Supplementation can be viable and important in the periods of the seasonality of pastures (Sousa et al., 2018).

The observed NDFI may indicate that this nutrient has limited forage intake. The lower intake of this nutrient (413.76 g/day of NDF) by Santa Inês sheep was also observed by Fontenele et al. (2011), who infer that food intake was limited by filling the ruminal compartment. According to Harper \& McNeill (2015), increased intake of NDF may limit a ruminant's ability to consume sufficient feed to meet his or her needs. In forage-based diets, rumen filling and fade rate usually control the ingestion. The highest ADLI observed in the animals kept in Aruana grasses can be attributed to the higher stem intake by these animals. These variables have a high and positive correlation (Table 6). Besides this, cultivar has a higher concentration of ADL in the stem (Table 1).

The animals kept in Aruana grasses remained in grazing activity during all the time that they had access to the pasture (9h), without performing any other activity in this period. This result is probably due to the lower supply of leaf blades observed in this cultivar (Table 2), according to that the animals spent more time searching for leaves to meet their daily requirement of forage intake. According to Pellegrini et al. (2011), sheep respond to a decrease in the percentage of available green leaves, increasing grazing time, to try to compensate for the reduction in diet quality, since the accessibility of leaves and the degree of maturity of the plant are closely related to the nutritive value of forage plants.

The higher bit rates resulted in higher DMI (g/ day) in Marandu pastures, and the lower supply of leaf blades in Aruana pastures (Table 2) justify the high rates. The increase in the bit rate can be caused by the reduction in DM availability and by the morphological composition of the pasture (Pedroso et al., 2004). The animals kept in Aruana pastures used the behavioral strategy in which the animals compensate for the reduction in pasture intake with the increase of grazing time. Consequently, this strategy implies an increase in the time of rumination, proved by the moderate correlation obtained between these variables (Table 6). Pompeu et al. (2009) observed $9.9 \mathrm{~h}$ of pasture for sheep in Tanzania pastures, the highest time obtained is the result of the absence of animal restraint, where only 9 hours of stay of the animals in the pasture was available in this work, this may have restricted the DMI.

The rumination time, independent of the grazed forage crop, was higher than the $6.6 \mathrm{~h}$ /day observed by Silva et al. (2016) in sheep kept on tropical pastures in the dry season. Even the quality of the forage was lower, the use of $1.5 \%$ LW of the concentrate supplement significantly improved the quality of the total diet of these animals. If the amount of concentrate is considered concerning the weight of the total intake obtained in this work (Table 2), it represents more than $60 \%$ of the animals' diet. The higher demand for time in grazing and rumination explains the less leisure time of the animals kept in Aruana grass pastures, with a high negative correlation between these activities (Table 6). Similar behavior was observed by Emerenciano Neto et al. (2018) for sheep in the pasture of Massai grass under different canopy heights. According to Pellegrini et al. (2011), the greater participation of the structural components in the pasture affected the increase in grazing time and the reduction in the leisure time of the animals.

The distribution of idle and rumination activities according to the schedule was similar to the results of Pompeu et al. (2009), with higher leisure frequencies between 11 p.m. and 5 a.m. and no grazing in the period from 2 a.m. to 5 a.m. for sheep in Tanzania pastures. The authors point out that primitive behaviors as protection of predators still causes the animals to prefer daytime grazing, even with high temperatures. The same period is also used for rumination. Feeding efficiency of the animals kept in Piatã pastures was a result of lower acid detergent lignin intake and grazing time (Table 3 and Table 4), with a high negative correlation between these activities (Table 6). The increase in rumination efficiency occurred when there was a greater supply of leaf blades, which allowed a higher rate of feed passage (Pereira et al., 2018). According to Carvalho et al. (2004), rumination efficiency is an essential mechanism in controlling the use of low digestibility foods.

With Aruana forage, the animal showed a higher daily weight gain and a more favorable feed conversion index. The higher crude protein intake with Aruana (that, however, was lower than that fed with Marandu) could have contributed to these results. But the other factor should be considered, as the longer grazing time. According to the longer time spent grazing, the sheep distributed their herbage intake (which was intermediate in comparison with the other forages) over a long grazing time. This condition could happen because they ate continuously and also permitted to slow the feed transit in gastro-intestinal tract, thus improve digestibility and, as a consequence, the efficiency of forage utilization and the growth performance.

The lowest feed conversion (FC) of animals kept in Aruana pastures was a result of the highest acid detergent lignin intake, and these variables showed a moderate negative correlation (Table 6). Higher forage intake is not always the most appropriate and should be observed with caution (Cabral et al., 2008), as conversion depends on the quality of forage intake. Therefore, food efficiency is an essential tool in livestock production systems, since an only high weight gain is not sufficient, these animals must also be efficient, with adequate intake and compatible performance.

\section{CONCLUSION}

Pasture structure and chemical composition of cultivars affect the nutrient intake, feeding behavior, and performance of sheep. The low leaf blade offer of the pasture of the Aruana grass negatively affects the 
feeding behavior of the sheep, but the crude protein in forage of this cultivar favors the nutrient intake, feed conversion, and performance of sheep.

\section{CONFLICT OF INTEREST}

The authors declare that there is no conflict of interest with any financial, personal, or other relationships with other people or organizations related to the material discussed in the manuscript.

\section{ACKNOWLEDGEMENT}

We thank CNPq and CAPES for financial support in developing the study and the scholarships granted. We also thank GEFOR (Grupo de Estudos em Forragicultura -UFRN) for assistance in executing this study.

\section{REFERENCES}

AOAC (Association of Official Analytical Chemists). 2000. Official methods of analysis. 17th edition. Washington, DC., USA.

Azevedo, E. B., C. H. E. C. Poli, D. B. David, G. A. Amaral, L. Fonseca, P. C. F. Carvalho, V. Fischer, \& S. T. Morris. 2014. Use of faecal components as markers to estimate intake and digestibility of grazing sheep. Livest. Sci. 165: 4250. https://doi.org/10.1016/j.livsci.2014.04.018

Bosa, R., C. Faturi, H. G. R. Vasconcelos, A. M. Cardoso, A. F. O. Ramos, \& J. C. Azevedo. 2012. Intake and apparent digestibility with different inclusion levels of coconut meal for sheep feeding. Acta Sci. Anim. Sci. 34: 57-62. https://doi. org/10.4025/actascianimsci.v34i1.11936

Burger, P. J., J. C. Pereira, A. C. Queiroz, J. F. C. Silva, S. C. Valadares Filho, P. R. Cecon, \& A. D. P. Casali. 2000. Ingestive behavior in Dutch calves fed diets containing different levels of concentrate. R. Bras. Zootec. 29: 236-242. https://doi.org/10.1590/S1516-35982000000100031

Cabral, L. S., J. W. Santos, J. T. Zervoudakis, J. G. Abreu, A. L. Souza, \& R. C. Rodrigues. 2008. Intake and feeding efficiency in feed-lot lambs. Rev. Bras. Saúde Prod. Anim. 9: 703-714.

Carvalho, C. G. G. P., A. J. V. Pires, F. F. Silva, C. M. Veloso, R. R. Silva, H. G. O. Silva, P. Bonomo, \& S. S. Mendonça. 2004. Ingestive behavior of dairy goats fed on cocoa meal or palm cake. Pesq. Agropec. Bras. 39: 919-925. https://doi. org/10.1590/S0100-204X2004000900012

Emerenciano Neto, J. V., G. S. Difante, A. M. Q. Lana, H. R. Medeiros, E. M. Aguiar, D. B. Montagner, \& J. S. Souza. 2018. Forage quality and performance of sheep in Massai grass pastures managed at pre-grazing canopy heights. S. Afr. J. Anim. Sci. 48: 1073-1081. https://doi.org/10.4314/sajas.v48i6.10

Ferreira D. F. 2011. Sisvar: a computer statistical analysis system. Ciênc. Agrotec. 35: 1039-1042. https://doi.org/10.1590/ S1413-70542011000600001

Fontenele, R. M., E. S. Pereira, M. S. S. Carneiro, P. G. Pimentel, M. J. D. Cândido, \& J. G. L. Regadas Filho. 2011. Nutrient intake and ingestive behavior of Santa Inês lambs fed diets with different levels of metabolizable energy. R. Bras. Zootec. 40: 1280-1286. https://doi.org/10.1590/ S1516-35982011000600017

Galli, J. R., C. A. Cangiano, \& H. H. Fernández. 1996. Ingestive behavior and consumption of grazing cattle. Rev. Arg. Prod. Anim. 16: 119-142.
Goes, R. H. T. B., M. M. Y. Carneiro, M. P. Osmari, K. A. Souza, R. T. Oliveira, \& C. J. S. Souza. 2018. Intake, digestibility, performance and carcass characteristics of ewes fed crambe replacing soybean meal in the diet. Acta Sci. Anim. Sci. 40: e37171. https://doi.org/10.4025/actascianimsci. v40i1.37171

Gómez, J. M. D., V. Fischer, C. H. E. C. Poli, P. C. F. Carvalho, E. J. Pegoraro, \& E. Macari. 2010. Effects of forage supply, grazing method, days of evaluation and breed on sheep behavior and temperament. R. Bras. Zootec. 39: 1840-1848. https://doi.org/10.1590/S1516-35982010000800029

Harper, K. J., \& D. M. Mcneill. 2015. The Role iNDF in the Regulation of Feed Intake and the Importance of Its Assessment in Subtropical Ruminant Systems (the Role of iNDF in the Regulation of Forage Intake). Agriculture 5: 778-790. https://doi.org/10.3390/agriculture5030778

Hodgson, J. 1985. The control of herbage intake in the grazing ruminant. Proc. Nutr. Soc. 44: 339-346. https://doi. org/10.1079/PNS19850054

Jochims, F., C. C. Pires, L. Griebler, A. M. S. Bolzan, F. D. Dias, \& D. B. Galvani. 2010. Feeding behavior and forage intake of ewe lambs on pearl millet pasture with or without supplementation. R. Bras. Zootec. 39: 572-581. https://doi. org/10.1590/S1516-35982010000300017

Luna, A. A., G. S. Difante, D. B. Montagner, J. V. Emerenciano Neto, I. M. M. Araújo, \& L. E. C. Oliveira. 2014. Accumulation of forage and morphogenic responses in forage grass by cutting. Biosci. J. 30: 1803-1810.

Mabrouk, C., N. Moujahed, R. Ouzrout, \& and C. Kayouli. 2008. Effects of supplementation on pasture intake by ewes in South-eastern of Algeria. Livest. Res. Rural Dev. 20; e43.

Pedroso, C. E. S., R. B. Medeiros, M. A. Silva, J. B. J. Jornada, J. C. Saibro, \& J. R. F. Teixeira. 2004. Sheep behavior at the pregnancy and at the lactation grazing on different phenological stages of annual ryegrass. R. Bras. Zootec. 33: 13401344. https://doi.org/10.1590/S1516-35982004000500028

Pellegrini, L. G., A. L. G. Monteiro, M. Neumann, P. C. F. Carvalho, A. L. P. Silva, S. B. C. Lustosa, \& A. C.R. S. Pellegrin. 2011. Behavior of lambs in ryegrass grazing (Lolium multiflorum) in different phenological phases submitted to nitrogen fertilization. Rev. Ceres 58: 329-335. https://doi.org/10.1590/S0034-737X2011000300013

Pereira, G. F., P. O. Lima, L. C. S. L. C. Assis, \& J.V. Emerenciano Neto. 2018. Nutrient intake, feeding behavior and performance of sheep fed hay of tropical grasses at different cutting intervals. Arq. Bras. Med. Vet. Zootec. 70: 897-904. https://doi.org/10.1590/1678-4162-9775

Pompeu, R. C. F. F., M. C. P. Rogério, M. J. D. Cândido, J. N. M. Neiva, J. L. L. Guerra, \& J. S. Gonçalves. 2009. Nutrient intake, ingestive behavior and performance of ovine fed grasses of tropical grasses at different intervals between cuts. R. Bras. Zootec. 38: 374-383. https://doi.org/10.1590/ S1516-35982009000200022

Saliba, E. O., E. P. Faria, N. M. Rodriguez, G. R. Moreira, I. B. M. Sampaio, J. S. Saliba, L. C. Gonçalves, I. Borges, \& A. L. C. C. Borges. 2015. Use of Infrared Spectroscopy to Estimate Fecal Output with Marker Lipe ${ }^{\circledR}$. Int. J. Food Sci. Nutr. 4: 1-10. https://doi.org/10.19070/2326-3350-SI04001

Sbrissia, A. F., P. G. D. Duchini, J. R. Echeverria, T. Miqueloto, A. Bernardon, \& L. F. Américo. 2017. Animal production on cultivated pasturelands in regions of temperate climate of Latin America. Arch. Latinoam. Prod. Anim., 25: 47-60.

Sollenberger, L. E., J. E. Mooreb, V. G. Allenc, \& C. G. S. Pedreira. 2005. Reporting Forage Allowance in Grazing Experiments. Crop Sci. 45: 896-900. https://doi.org/10.2135/ cropsci2004.0216

Sousa, S. V., M. J. Araújo, T. P. D. Silva, C. A. T. Marques, J. N. C. Torreão, L. R. Bezerra, I. S. S. Lima, \& F. P. Gottardi. 2018. Dietary supplementation for Santa Inês hair ewes 
on pasture at pre- and postpartum periods: dry matter intake, digestibility, milk production, and mineral metabolism. Trop. Anim. Health. Pro. 50: 1903-19012. https://doi. org/10.1007/s11250-018-1643-2

Silva, L. F. N., G. S. Difante, L. S. Fernandes, I. M. M. Araujo, J. V. Emerenciano Neto, M. G. Costa, \& N. R. O. Felisberto. 2016. Ingestive behavior of sheep in Panicum and Brachiaria pastures in dry season. Biosci. J. 32: 1018-1024. https://doi.org/10.14393/BJ-v32n4a2016-32945

Tarazona, A. M., M. C. Ceballos, J. F. Naranjo, \& C. A. Cuartas. 2012. Factores que afectan el comportamiento de consumo y selectividad de forrajes en rumiantes. Rev. Colom. Cienc. Pecua. 25: 473-487.

Tilley, J. M. A. \& R. A. Terry. 1963. A two-stage technique for the in vitro digestion of forage crops. J. Br. Grassl. Soc. 18: 104-111. https://doi.org/10.1111/j.1365-2494.1963.tb00335.x

Van Soest, P. J., J. D. Robertson, \& B. A. Lewis. 1991. Methods for dietary fiber, neutral detergent fiber, nonstarch polysaccharides in relation to animal nutrition. J. Dairy Sci. 74: 3583-3597. https://doi.org/10.3168/jds. S0022-0302(91)78551-2 